\title{
Evaluation of Phosphorus Sources and Rates on The Yield and Quality of Fertigated Potato Grown in Sandy Soil
}

\author{
S.T. Abou zeid and Amal L. Abd El-Latif \\ Soil Sciences Dept., Fac. Of Agriculture, Cairo University, Giza, Egypt.
}

\begin{abstract}
FIELD experiment was performed in the sandy soil at El-Sadat City, Menoufiea A Governorate, Egypt, for two consuctive seasons (2013 and 2014) to investigate the effect of different sources and rates of phosphorus fertilizers on yield and tuber quality of potato (Solanum tuberosum L.) Cv. Diamante grown on sandy soil. The experiment was conducted under drip irrigation system in split design with three replicates. Four sources of phosphorus were used: phosphoric acid $\left(\mathrm{H}_{3} \mathrm{PO}_{4}\right)$, mono ammonium phosphate (MAP), ammonium poly phosphate (APP) and urea phosphate (UP) with three rates, 50, 75 and $100 \mathrm{~kg}_{2} \mathrm{O}_{5} /$ fed applied through irrigation water.The results showed significant differences among the sources and rates of phosphorus fertilizers on total yield, tuber weight, tuber diameter, specific gravity and starch content of tuber. The data revealed that UP and APP were the best among other sources. Data also showed that yield and quality of tuber increased with increasing phosphorus rates up to 100 $\mathrm{kg} \mathrm{P}_{2} \mathrm{O}_{5} /$ fed. The data also presented that in both seasons, UP gave the highest $\mathrm{P}$ concentration in soil compared with other sources of phosphorus.
\end{abstract}

Keywords : Potato, Phosphorus fertilizers, Fertigation, Tuber quality.

\section{Introduction}

Potato (Solanum tuberosum L.) is one of the most important vegetables in Egypt which gained a considerable importance as an export to European markets (Eleiwa et al., 2012). Potato is a short-cycle crop and present high production capacity, it is highly influenced by the application of different nutrients to the soil (Luz et al., 2013).

It has been usually applied high rates of phosphate fertilizers in the cultivation, aimed at achieving high levels of tuber yield and larger tuber (Luz et al., 2013). Phosphorus has various effects on tuber quality, such as tuber size and percentage of dry matter (indicated by specific gravity) of the tuber (Freeman et al., 1998 and Rosen et al., 2014).

Kafkafi (1994) considered fertigation as an efficient method for providing and supplying available forms of immobile elements such as $\mathrm{P}$, at a desirable level in root zone. Also successful P-fertigation has been reported by Papadopoulos, (2000). As regards to the effect of P source on yield, Brito et al. (2000) revealed that the highest commercial yield was obtained with $\mathrm{H}_{3} \mathrm{PO}_{4}$ applied through trickle irrigation. Papadopoulos and Ristimaki-Leena (2000) indicated that UP as a source of $\mathrm{P}$ gave the highest yield compared with DAP and MAP.

This study was initiated to evaluate the effect of different sources and rates of phosphorous fertilizers on yield and quality of potatoes tuber grown in sandy soil under fertigation system.

\section{Material and Methods}

A field experiment was established at El-Sadat City, Menoufia Governorate, Egypt, during two successive Fall (nili) seasons 2013 and 2014. Potato (Solanum tuberosum L.). Cv. Diamante was chosen as an indicator plant in this study. The split plot design was used with three replicates under drip irrigation system. The plot area was $17.5 \mathrm{~m}^{2}(3.5 \mathrm{~m} \times 5 \mathrm{~m})$. Some physical and chemical properties of initial soil under investigation are shown in Table 1. 
TABLE 1. Particles size distribution and chemical analysis of soil sample of the experimental site

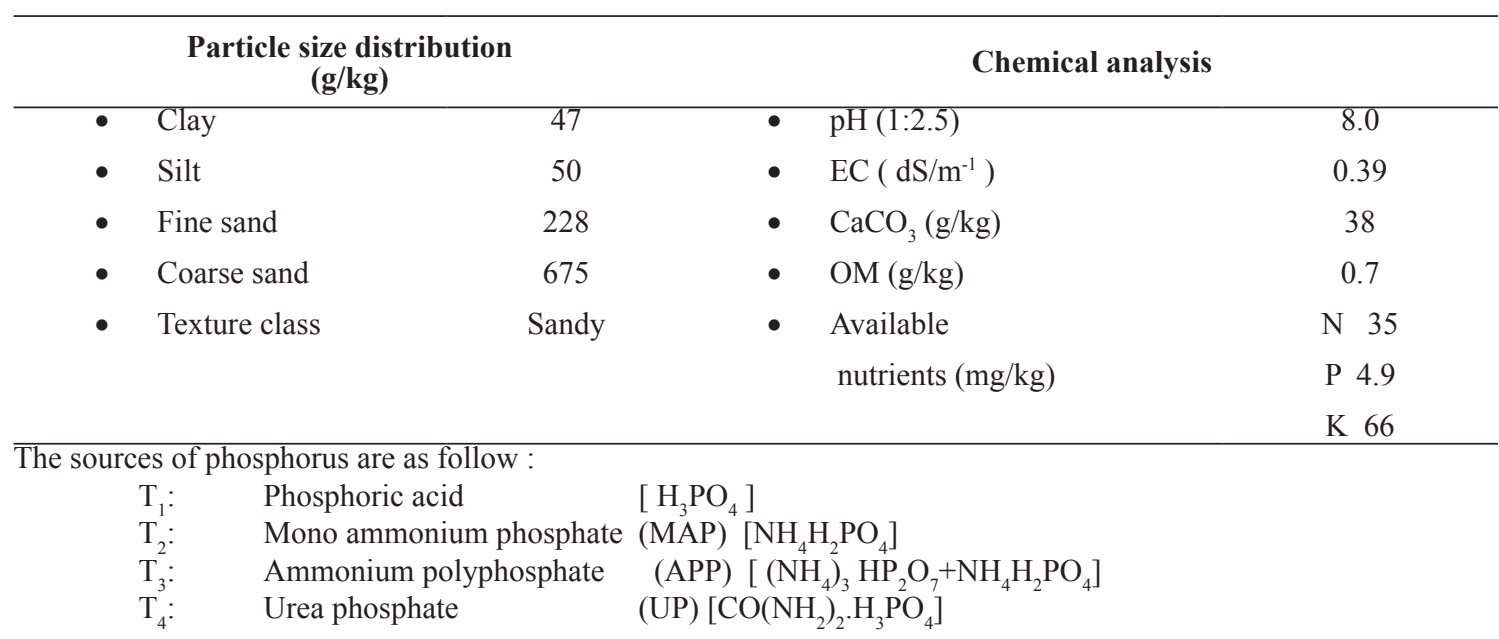

Three rates of phosphorus were used 50, 75 and $100 \mathrm{~kg} \mathrm{P}_{2} \mathrm{O}_{5} / \mathrm{Fed}$, assigned as $\mathrm{R}_{1}, \mathrm{R}_{2}$ and $\mathrm{R}_{3}$ respectively. Both nitrogen and potassium were applied according to recommendation of Ministry of Agriculture and Land Reclamation. All P sources $\mathrm{H}_{3} \mathrm{PO}_{4}$, MAP, APP and UP were applied three times/week.

Whole seed tubers were planted in row $0.70 \mathrm{~m}$ apart and $0.25 \mathrm{~m}$ within the row on October $15^{\text {th }}$.

\section{Soil analysis}

Soil samples $(0-30 \mathrm{~cm})$ were taken from the experimental site at the beginning and the end of the experiment. Particle size distribution was carried according to Gee and Bander (1986). Total $\mathrm{CaCO}_{3}$ was dertermined using Collins calicimeter (Sparks, 1996). pH, EC, organic matter, available $\mathrm{K}, \mathrm{P}$ and $\mathrm{N}$ were determined according to Sparks, (1996).

\section{Data for plant recorded}

Each experimental plot was harvested after 120 days of planting, then total tuber yield (ton/ fed) were recorded. For each plot h arvested tubers were graded into three categories according to tuber weight i.e. small $(<30 \mathrm{~g})$, medium $(30-60$ g) and large tubers ( $>60 \mathrm{~g})$. Specific gravity of tubers was estimated, where :

specific gravity = weight in the air/weight in the air-weight in the water.

Starch (\%) was determined according to the method described by Nandutu et al. (2002). Phosphorus was determined in the fourth leaf from the top after 75 days from planting and in tubers according to the method described by Pierzynski (2000). The obtained data were statically analyzed according to Snedecor and Cochran (1990).

Egypt. J. Soil Sci., 58, No.1 (2018)

\section{Results and Discussion}

Yield

The tuber weight of each class category as affected by phosphorus fertilizer sources at harvest is presented in Tables $2 \& 3$. The data indicated significant differences between the sources and the rates of $\mathrm{P}$ fertilizer in terms of the grades of tuber weight. In both seasons potatoes of APP treatment had significantly lower yield of small tuber compared to that obtained with other sources.

Also, UP and APP had significantly higher tuber yield of medium and large size compared to those supplied with other P sources. These results were in agreement with Salem et al. (2004). The data showed that, as the $\mathrm{P}$ rate increased, the yield of medium $(30-60 \mathrm{~g})$ and large $(>60 \mathrm{~g})$ size tubers increased. In both seasons, potatoes of the treatment of $100 \mathrm{P}_{2} \mathrm{O}_{5} /$ fed. had significantly lower weight of small tuber size comparing to other $\mathrm{P}$ fertilizer rates. These results agree with those of Curless et al. (2004).

Data of Table 3 indicate that in both seasons, total yield was significantly affected by the $\mathrm{P}$ fertilizer sources. Potato of the treatments of APP and UP had significantly highest total yields comparing to other sources. These results are in agreement with Papadopoulos (2000) who found that UP gave the highest yield.

The results showed that the increase of the yield was proportionally with the increase of $\mathrm{P}$ rate of application. Agreeing with these results, Luz et al. (2013) mentioned that application of high rates of phosphate fertilizers produced high levels of both potatoes yield and larger tubers. 
TABLE 2. Effect of source and rate of $P$ fertilizers on yield of small and medium potato tubers

\begin{tabular}{|c|c|c|c|c|c|c|c|c|}
\hline \multirow{5}{*}{ Sources } & \multicolumn{8}{|c|}{ Yield (ton/fed) } \\
\hline & \multicolumn{5}{|c|}{ Small tubers } & \multicolumn{2}{|c|}{ Medium tubers } & \multirow[b]{4}{*}{ Mean } \\
\hline & & & & Seas & & & & \\
\hline & \multicolumn{7}{|c|}{ Rate of $P$ application } & \\
\hline & R1 & $\mathbf{R 2}$ & $\mathbf{R 3}$ & Mean & R1 & $\mathbf{R 2}$ & R3 & \\
\hline T1 & 0.950 & 0.900 & 0.880 & $0.911 \mathrm{a}$ & 6.46 & 6.92 & 7.16 & $6.85 b$ \\
\hline $\mathrm{T} 2$ & 0.942 & 0.890 & 0.870 & $0.901 \mathrm{~b}$ & 6.51 & 7.20 & 7.45 & $6.94 b$ \\
\hline $\mathrm{T} 3$ & 0.736 & 0.617 & 0.609 & $0.654 \mathrm{c}$ & 7.60 & 7.92 & 8.49 & $8.00 \mathrm{a}$ \\
\hline $\mathrm{T} 4$ & 0.730 & 0.610 & 0.600 & $0.647 \mathrm{~d}$ & 7.65 & 8.00 & 8.56 & $8.07 \mathrm{a}$ \\
\hline Mean & $0.839 \mathrm{a}$ & $0.755 b$ & $0.740 \mathrm{c}$ & & $6.97 \mathrm{c}$ & $7.51 \mathrm{~b}$ & $7.92 \mathrm{a}$ & \\
\hline \multirow[t]{3}{*}{ LSD 0.05} & Source & & 0.003 & & \multicolumn{4}{|c|}{0.177} \\
\hline & Rate & & 0.002 & & & & & \\
\hline & \multicolumn{8}{|c|}{ Season 2014} \\
\hline $\mathrm{T} 1$ & 1.01 & 0.950 & 0.880 & $0.947 \mathrm{a}$ & 5.78 & 6.00 & 6.59 & $6.13 c$ \\
\hline $\mathrm{T} 2$ & 0.985 & 0.940 & 0.870 & $0.932 b$ & 5.90 & 6.12 & 6.99 & $6.34 \mathrm{~b}$ \\
\hline $\mathrm{T} 3$ & 0.785 & 0.710 & 0.660 & $0.718 \mathrm{c}$ & 8.13 & 8.85 & 9.16 & $8.71 \mathrm{a}$ \\
\hline $\mathrm{T} 4$ & 0.780 & 0.702 & 0.653 & $0.712 \mathrm{~d}$ & 8.15 & 8.85 & 9.17 & $8.72 b$ \\
\hline Mean & $0.890 \mathrm{a}$ & $0.825 \mathrm{~b}$ & $0.766 \mathrm{c}$ & & $6.99 \mathrm{c}$ & $7.46 \mathrm{~b}$ & $7.97 \mathrm{a}$ & \\
\hline \multirow[t]{2}{*}{ LSD 0.05} & Source & & 0.002 & & & \multicolumn{2}{|c|}{0.014} & \\
\hline & Rate & & 0.003 & & & \multicolumn{2}{|c|}{0.025} & \\
\hline
\end{tabular}

TABLE 3. Effect of source and rate of $P$ fertilizers on large tubers and total yield of potato

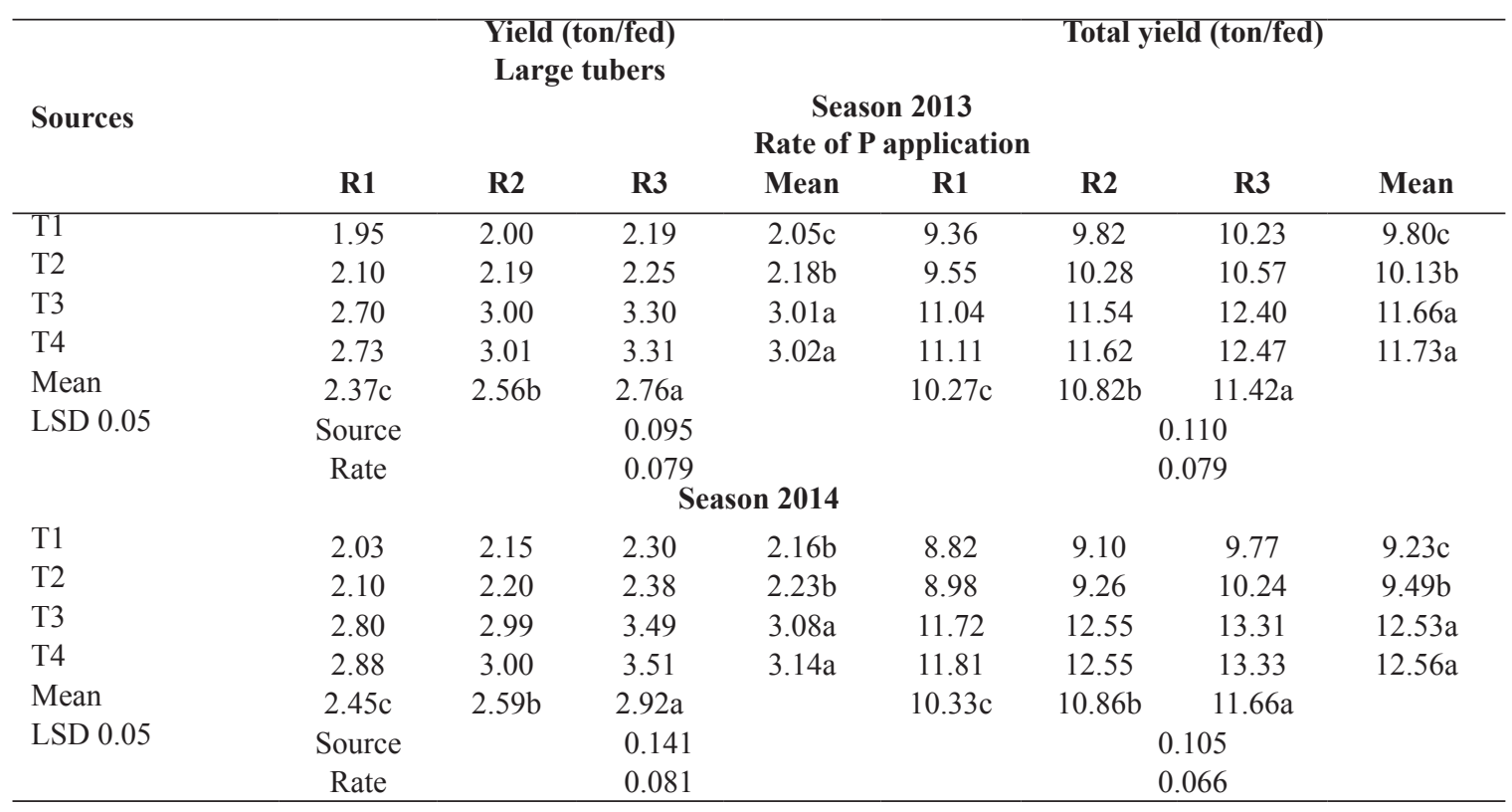

Data in Table 4 indicated that all sources of phosphorus had similar effect on tuber weight and size in both seasons. Both UP and APP were superior than the other $\mathrm{P}$ fertilizers sources.

In both seasons, increasing phosphorus rate significantly affected tuber weight and size. For all sources of $\mathrm{P}$ fertilizers, application of 100 $\mathrm{kg} \mathrm{P}_{2} \mathrm{O}_{5} /$ fed produced maximum tuber weight and size. These results agree with those of AlvarezSnchez et al. (1999).
Tuber quality

The tuber specific gravity is a measure of quality of potato tuber which is related to the dry matter content of the tuber, The specific gravity was positively affected by $\mathrm{P}$ fertilization (Table 5). The specific gravity of potatoes of treatments of the high rate of UP and APP were lower than those recorded for other sources and rates of $\mathrm{P}$ fertilizers treatments. Significant differences were obtained between both UP and APP and the other sources in both seasons, while the differences 
between UP and APP were insignificant. In this concern, Rosen et al. (2014) found that the specific gravity levels were maximized by the lowest rates of P applied. Also, Freeman et al., (1998) observed reduction in the specific gravity of potato tuber as a function of $\mathrm{P}$ rates. These results were in agreement with Khan et al. (2010) where they reported that potatoes with low specific gravity are preferred for preparation of chips and French fries. Potatoes with low specific gravity are used for canning. However, potatoes of very high specific gravity $\left(1.10 \mathrm{~g} / \mathrm{cm}^{3}\right)$ may not be suitable for French Fries production because they become hard or biscuit like. So purpose of growing potato should be kept in mind.

TABLE 4. Effect of source and rate of $P$ fertilizers on weight and size of potato tubers

\begin{tabular}{|c|c|c|c|c|c|c|c|c|}
\hline \multirow{3}{*}{ Sources } & \multicolumn{5}{|c|}{ Average tuber weight (g) } & \multicolumn{3}{|c|}{ Tuber size (cm) } \\
\hline & \multicolumn{8}{|c|}{$\begin{array}{c}\text { Season } 2013 \\
\text { Rate of application }\end{array}$} \\
\hline & R1 & R2 & R3 & Mean & R1 & $\mathbf{R 2}$ & R3 & Mean \\
\hline T1 & 151.2 & 158.3 & 160.2 & $156.57 b$ & 6.24 & 6.30 & 6.48 & $6.37 b$ \\
\hline $\mathrm{T} 2$ & 152.3 & 159.9 & 162.3 & $162.17 b$ & 6.35 & 6.45 & 6.59 & $6.48 \mathrm{~b}$ \\
\hline $\mathrm{T} 3$ & 155.3 & 158.2 & 173.3 & $162.27 \mathrm{a}$ & 6.65 & 6.70 & 6.80 & $6.72 \mathrm{a}$ \\
\hline $\mathrm{T} 4$ & 157.6 & 160.2 & 174.5 & $164.10 \mathrm{a}$ & 6.70 & 6.79 & 6.88 & $6.79 a$ \\
\hline Mean & $154.1 \mathrm{c}$ & $159.2 b$ & $167.57 \mathrm{a}$ & & $6.52 b$ & $6.56 \mathrm{ab}$ & $6.69 a$ & \\
\hline \multirow{2}{*}{ LSD 0.05} & Source & & 2.739 & & \multicolumn{4}{|c|}{0.148} \\
\hline & Rate & & 1.298 & & \multicolumn{4}{|c|}{0.152} \\
\hline \multicolumn{9}{|c|}{ Season 2014} \\
\hline $\mathrm{T} 1$ & 152.1 & 158.3 & 162.2 & $157.53 b$ & 6.36 & 6.45 & 6.53 & $6.45 b$ \\
\hline $\mathrm{T} 2$ & 154.0 & 159.4 & 165.3 & $159.57 \mathrm{~b}$ & 6.40 & 6.55 & 6.66 & $6.54 b$ \\
\hline $\mathrm{T} 3$ & 160.3 & 168.2 & 174.3 & $167.6 \mathrm{a}$ & 6.80 & 6.90 & 7.10 & $6.93 a$ \\
\hline $\mathrm{T} 4$ & 161.2 & 169.3 & 176.7 & $169.07 \mathrm{a}$ & 6.85 & 6.99 & 7.20 & $7.01 \mathrm{a}$ \\
\hline Mean & $156.9 \mathrm{c}$ & $163.8 b$ & $169.62 \mathrm{a}$ & & $6.60 \mathrm{c}$ & $6.72 b$ & $6.87 \mathrm{a}$ & \\
\hline \multirow{2}{*}{ LSD 0.05} & Source & \multicolumn{3}{|c|}{3.702} & \multicolumn{4}{|c|}{0.153} \\
\hline & Rate & & 1.117 & & \multicolumn{4}{|c|}{0.073} \\
\hline
\end{tabular}

TABLE 5. Effect of source and rate of $P$ fertilizers on specific gravity and starch content of potato

Sources

Season 2013

Rate of $P$ application

\begin{tabular}{|c|c|c|c|c|c|c|c|c|}
\hline & R1 & $\mathbf{R 2}$ & R3 & Mean & R1 & $\mathbf{R 2}$ & R3 & Mean \\
\hline T1 & 1.092 & 1.089 & 1.082 & $1.088 \mathrm{a}$ & 12.22 & 12.50 & 13.16 & $12.63 \mathrm{c}$ \\
\hline $\mathrm{T} 2$ & 1.090 & 1.086 & 1.080 & $1.085 \mathrm{a}$ & 14.11 & 14.30 & 15.25 & $14.55 b$ \\
\hline $\mathrm{T} 3$ & 1.075 & 1.063 & 1.061 & $1.066 \mathrm{~b}$ & 17.10 & 17.21 & 19.99 & $18.10 \mathrm{a}$ \\
\hline $\mathrm{T} 4$ & 1.071 & 1.060 & 1.059 & $1.063 \mathrm{~b}$ & 17.25 & 17.36 & 20.48 & $18.36 \mathrm{a}$ \\
\hline Mean & $1.082 \mathrm{a}$ & $1.074 \mathrm{~b}$ & $1.071 \mathrm{~b}$ & & $15.17 \mathrm{~b}$ & $15.34 \mathrm{~b}$ & $17.22 \mathrm{a}$ & \\
\hline LSD 0.05 & Source & & 0.006 & & \multicolumn{4}{|c|}{1.163} \\
\hline \multirow{2}{*}{\multicolumn{9}{|c|}{ Season 2014}} \\
\hline & & & & & & & & \\
\hline T1 & 1.094 & 1.089 & 1.082 & $1.088 \mathrm{a}$ & 12.71 & 13.10 & 13.82 & $13.21 \mathrm{~b}$ \\
\hline $\mathrm{T} 2$ & 1.090 & 1.085 & 1.080 & $1.085 \mathrm{a}$ & 12.82 & 13.25 & 13.93 & $13.33 b$ \\
\hline T3 & 1.079 & 1.069 & 1.066 & $1.071 \mathrm{~b}$ & 18.23 & 19.85 & 21.70 & $19.93 \mathrm{a}$ \\
\hline $\mathrm{T} 4$ & 1.073 & 1.066 & 1.061 & $1.067 \mathrm{~b}$ & 18.30 & 19.90 & 21.72 & $19.97 \mathrm{a}$ \\
\hline Mean & $1.084 \mathrm{a}$ & $1.077 \mathrm{~b}$ & $1.072 \mathrm{c}$ & & $15.51 \mathrm{c}$ & $16.52 \mathrm{~b}$ & $17.79 a$ & \\
\hline \multirow[t]{2}{*}{ LSD 0.05} & Source & & 0.013 & & \multicolumn{4}{|c|}{0.511} \\
\hline & Rate & & 0.003 & & & & & \\
\hline
\end{tabular}

Data in Table 5 illustrate that starch in potato tuber was significantly affected by both sources and rates of $\mathrm{P}$ application. Among all $\mathrm{P}$ sources, starch content of UP treatment was the highest.
In both seasons, increasing phosphorus rate significantly affected starch content in potato tuber. These results are in agreement with those of Stark and Love (2003) who reported that, the

Egypt. J. Soil Sci., 58, No.1 (2018) 
influences of $\mathrm{P}$ on solids are expected as $\mathrm{P}$ tends to increase starch synthesis and hasten crop maturity. Also, Fernandes et al. (2015) found that as the rate of $\mathrm{P}$ increased, the starch content increased. Phosphorus participates in a number of key enzymes involved in the regulation of starch synthesis (sucrose phosphate synthase, fructose- 1,6 - bisphosphatase and ADP-glucose pyrophosphorylase) (Taiz and Zeiger, 2013) and is also part of its composition, being connected to the amylopection fraction of starch, in the form of phosphate ester (Nielsen et al. 1994).

\section{Phosphorus content in potato leaves and tubers}

Data in Table 6 indicated that sources of $\mathrm{P}$ fertilizer had significant effect on $\mathrm{P}$ percentage of leaves and tubers at harvest (120 days after planting). In both seasons, $P$ percentage in leaves and tubers of potatoes which supplied with UP was significantly higher than those fertilized with other sources. These results are similar to those reported by Al-Showk et al. (1987). Eissa (2014) also found that phosphate availability and therefore, plant phosphorus absorption increased with urea phosphate.

The data also indicated that increasing phosphorus rate significantly affected $\mathrm{P}$ percentage in leaves and tuber. Similar trend was obtained by Fernandes et al. (2015).

\section{Available phosphorus}

Phosphorus content in soil at the beginning and the end of experiment are presented in Table 7. The soil P content significantly increased as the rate of applied $\mathrm{P}$ increased.

Regarding, P source, the data illustrated that UP and APP give the highest values of P content in soil comparing with other sources. Similar results were obtained by Papadopoulos, (2000) who found that more positive results obtained with UP. Also, he reported that the concentration of $\mathrm{P}$ in soil solution is increased due to the induced acidification by UP. Eissa (2014) and Eissa et al. (2010) reffered the superiority of urea phosphate to the acidity of this fertilizer .

TABLE 6. Effect of source and rate of $P$ fertilizers on phosphorus (\%) of potato leaves and tubers

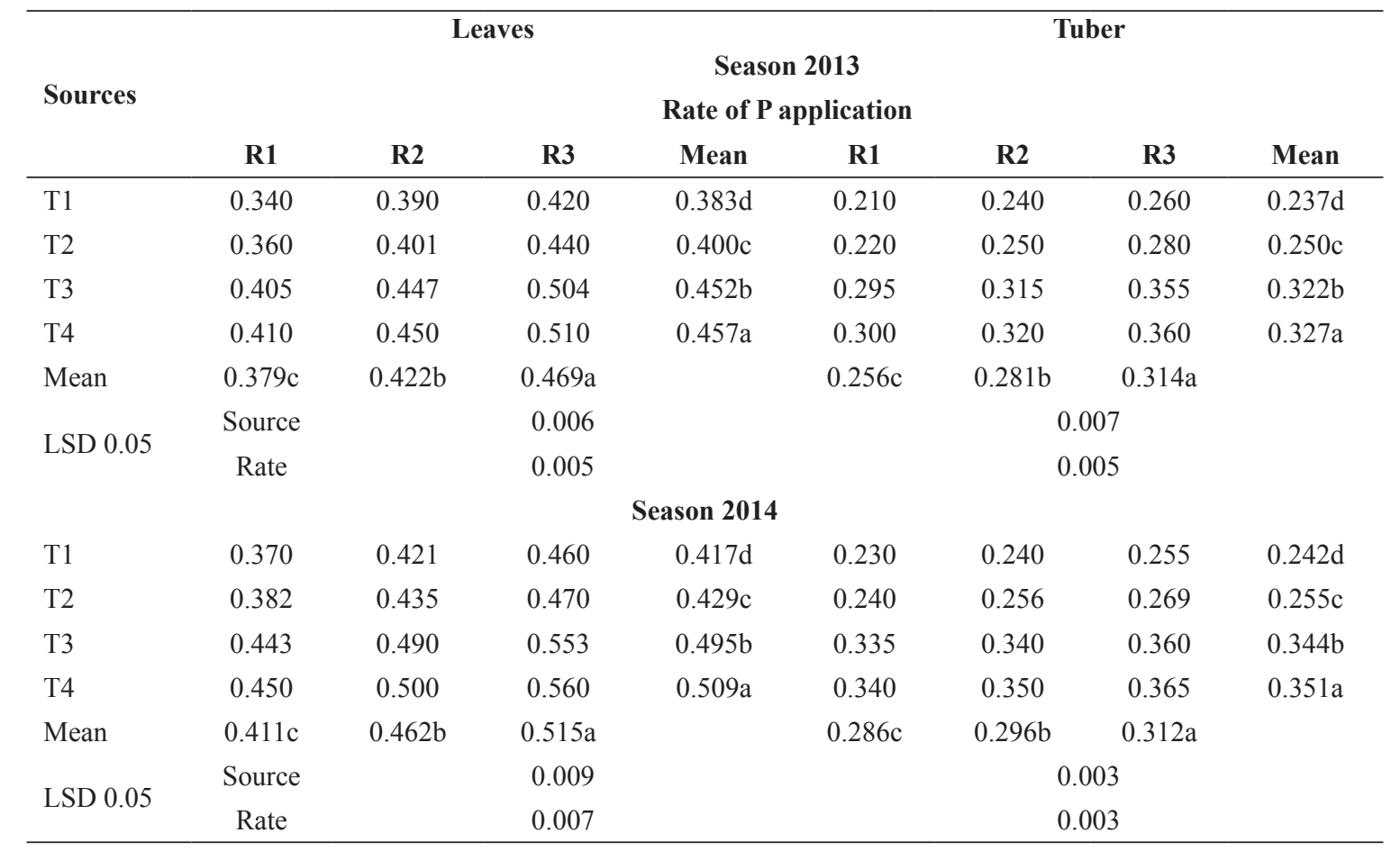


TABLE 7 . Phosphorus content in soil $(\mathrm{mg} / \mathrm{kg})$ at the beginning and the end of experiment

\begin{tabular}{|c|c|c|c|c|c|c|c|c|}
\hline \multirow{4}{*}{ Sources } & \multicolumn{4}{|c|}{ At the beginning of experiment } & \multicolumn{4}{|c|}{ At the end of experiment } \\
\hline & \multicolumn{8}{|c|}{ Season 2013} \\
\hline & \multicolumn{8}{|c|}{ Rate of $P$ application } \\
\hline & R 1 & R2 & R3 & Mean & R1 & R2 & R3 & Mean \\
\hline $\mathrm{T} 1$ & 7.50 & 9.12 & 11.50 & $9.37 \mathrm{~b}$ & 9.30 & 11.20 & 13.87 & $11.46 \mathrm{~b}$ \\
\hline $\mathrm{T} 2$ & 7.62 & 9.19 & 11.63 & $9.48 b$ & 9.40 & 11.31 & 13.90 & $11.54 \mathrm{~b}$ \\
\hline $\mathrm{T} 3$ & 8.05 & 10.45 & 12.18 & $10.22 \mathrm{a}$ & 9.95 & 12.75 & 14.75 & $12.48 \mathrm{a}$ \\
\hline $\mathrm{T} 4$ & 8.10 & 10.50 & 12.20 & $10.27 \mathrm{a}$ & 10.00 & 12.83 & 14.80 & $12.55 \mathrm{a}$ \\
\hline Mean & $7.82 \mathrm{c}$ & $9.81 \mathrm{~b}$ & $11.88 \mathrm{a}$ & & $9.67 \mathrm{c}$ & $12.02 \mathrm{~b}$ & $14.33 \mathrm{a}$ & \\
\hline \multicolumn{9}{|c|}{ L.S.D 0.05} \\
\hline Sources & \multicolumn{5}{|c|}{0.177} & \multicolumn{2}{|c|}{0.107} & \\
\hline Rates & \multicolumn{3}{|c|}{0.075} & & & \multirow{2}{*}{\multicolumn{2}{|c|}{0.085}} & \\
\hline \multicolumn{7}{|c|}{ Season 2014} & & \\
\hline $\mathrm{T} 1$ & 7.90 & 9.38 & 11.61 & $9.53 b$ & 9.98 & 13.68 & 15.33 & $12.99 \mathrm{~b}$ \\
\hline $\mathrm{T} 2$ & 7.95 & 9.45 & 11.70 & $9.70 \mathrm{~b}$ & 10.00 & 13.76 & 15.40 & $13.05 \mathrm{~b}$ \\
\hline $\mathrm{T} 3$ & 8.80 & 10.20 & 12.50 & $10.50 \mathrm{a}$ & 10.70 & 13.80 & 15.60 & $13.37 \mathrm{a}$ \\
\hline $\mathrm{T} 4$ & 8.89 & 10.25 & 12.54 & $10.56 \mathrm{a}$ & 10.79 & 13.86 & 15.61 & $13.42 \mathrm{a}$ \\
\hline Mean & $8.31 \mathrm{c}$ & $9.82 b$ & $12.09 \mathrm{a}$ & & $10.36 \mathrm{c}$ & $13.78 b$ & $15.48 \mathrm{a}$ & \\
\hline \multicolumn{9}{|c|}{ L.S.D 0.05} \\
\hline Sources & \multirow{2}{*}{\multicolumn{5}{|c|}{$\begin{array}{l}0.184 \\
0.162\end{array}$}} & \multicolumn{2}{|c|}{0.079} & \\
\hline Rates & & & & & & & 0.083 & \\
\hline
\end{tabular}

\section{References}

Al-Showk, A.M., Westerman, R.L. and Weeks, D.L. (1987) Influence of phosphorus source and rates on soil $\mathrm{pH}$, extractaue phosphorus and DTPAextractable micronutrients. J. Soil Sci. 144 (1), 36-42.

Alvarez-Sanchez, E. Etchevers, J.D., Ortiz, J., Nunez, R., Volke, V., Tijerina, L. and Martinez, A. (1999) Biomass production and phosphorus accumulation of potato as affected by phosphorus nutrition. Journal of Plant Nutrition, 22 (1), 205-217.

Brito, L.T., Soarces, J.M.; Faria, C.M. and Costa, N.D. (2000) Sources of phosphorus applied through fertigation in muskmelon. Revista Brasileira Engenharia Ambiental, 4 (1), 19-22.

Curless, M.A., Keith, A.K. and Phillips E.S. (2004) Nitrogen and Phosphorus availability from liquid dairy manure to potatoes. Amer. J. of Potato Res. 82, 287-297.

Eissa, M.A. (2014) Effect of low and high frequency of phosphorus fertigation on movement of different forms of phosphorus fertilizers in sandy calcareous soils world. Applied Sciences Journal, 31 (12), 2045-2050.

Eissa, M.A., Nafady, M., Ragheb, H. and Attia, K. (2010) Management of phosphorus fertigation for drip irrigated wheat under sandy calcareous soils. World journal of Agricultural Sciences, 6 (5), 510516.

Egypt. J. Soil Sci., 58, No.1 (2018)
Eleiwa, M.E., Ibrahim, S.A. and Mohamed, M.F. (2012) Combined effect of NPK levels and foliar nutritional compounds on growth yield parameters of potato plants (Solanum tuberosum L.). African J. Microb. Res. 6, 5100-5109.

Fernandes, A.M., Soratto., R.P.; Moreno, L. A and Evangelista, R.M. (2014) Effect of phosphorus nutrition on quality of fresh tuber of potato cultivars. Bragantia Campinas, 74, 102-109.

Freeman, K.L., Franz, P.R. and Jong, R.W. (1998)Effect of phosphorus on the yield, quality and petiotar phosphorus concentrations of potatoes (cv. Russer Burbank and Kennebec) grown in the kransozem and duplex soils of Victoria. Australian Journal of Experimental Agriculture, 38, 83-93.

Gee, G.W. and Bander, J.W. (1986) Particle size analysis in: Klute A. (Ed.), Methods of Soil Analysis, Part 1: Physical and Mineralogical Methods. Soil Sci. Soc. Amer., Madison, WI, PP. 383-411.

Kafkafi, U. (1994) Combined irrigation and fertigation in arid zones. Iserael. J. Plant. Sci. 42, 301-320. cited by Mohammed et al. (2004).

Khan, M.Z., Aktar, M.E., Safdar, M.N., Mahmoud, M.M., Ahmed, S. and Ahmed, N. (2010) Effect of source and level of potash on yield and quality of potato tuber. Pak. J. Bot. 42 (5), 3137-3145.

Luz, J.M.Q., Queiroz, A.A., Borges, M., Oliverira, R.C., Leite, S.S. and Cardoso, R.R. (2013) Influene 
of phosphate fertilization on phosphorus levels in foliage and tuber yields of the potato cv. Agata Semina: Ciencias Agrarias, 34, 649-656.

Nandutu, A., Carasco, J. and Hagenimana, V. (2002) Using sweet potato amylase extract for determination of starch in food stuffus. $J$ Food. Technol. Afr. 5 (2) , 66-69.

Nielsen, T.H, Wischman, B. Envelodsen, K. and Moller, B.L. (1994) Strach phosphorylation in potato tubers proceeds concurrently with de nova biosynthesis of starch. Plant Physiology, 105, 111-117.

Papadopoulos, I. (2000) Fertigation: present situation and future prospects. In: plant nutrient management under pressurized irrigation systems in the Mediterranean region. Ryan, J. (Ed), Proceeding of the IMPHOS. International Fertigation Work Shop organized by the World. Phosphate Institute (IMPHOS). Amman Jordan. ICARDA, Aleppo, Syria, pp. 232-245.

Papadopoulos, I. and Ristimaki-Leena, M. (2000) Nitrogen and Phosphorus fertigation of tomato and eggplant. Acta Horticulturae (511), 73-79.

Pierzynski, G.M. (2000) Methods of phosphorus analysis for soils, sediments, residuals, and waters. Southern Cooperative series Bulletin No. 396, June.
Rosen, C.J., Kelling, K.A., Stark, J.C. and Porter, G.A. (2014) Optimizing phosphorus fertilizer management in potato production. American Journal of Potato Research, 91, 145-160.

Salem, A.T., Kilany, A.E. and Shaker, G.S. (2004) The influence of NPK, phosphorus source and potassium foliar application on growth and fruit quality of Thompson seedless grapevines. Acta Horticulturae, 640, 163-173.

Snedecor, G.W. and Cochran, W.G. (1990) "Statistical Methods."The lowa state univ. $7^{\text {th }}$ ed. pp. 507.

Sparks, D.L. (1996) "Methods of Soil Analysis. Part 3, Chemical Methods". Soil Science Society of America; and American Society of Agronomy. book series, no. 5, Madison.WI. USA.

Stark, J.C. and Love, S.L. (2003) Tuber quality : In: Potato Production Systems, Ed.: Stark, J.C. and Love, S.L. 329-343. Moscow: University of Idaho Extension.

Taiz, L. and Zeiger, E. (2013) Fisiologia vegetal. Porto Alegre: Artmed Universidade Estadual de camponasUNICAMP. (2011). Tabela brasileira de composiçao de alimentos. Retrieved from August 8, 2014 . .

(Received:30/3/2016: accepted:15/5/2016)

\footnotetext{
تقييم مصادر ومعدلات الأسمدة الفوسفاتية على محصول وجودة البطاطس النامية فى

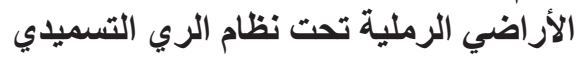
سيد طه أبو زيد و أمل لطفى عبد اللطيف

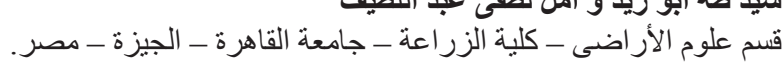

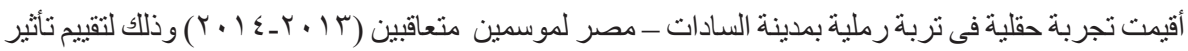
مصادر ومعدلات مختلفة من الأسمدة الفوسفاتية على المحصول الكلى وجودة درنة البطاطس لصنف دئف دايمونت. نفذت التجربة تحت نظام الري بالتتقيط وأستخدم فيها التصميم الإحصائى لنظام القطع المنشقة في ثلاث الثاث

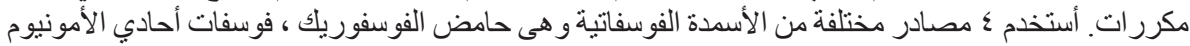

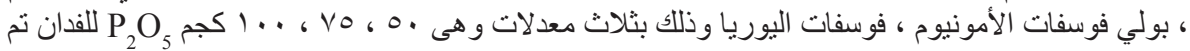
إضافتهم فى نظام الري بالتنقيط.

وبمقارنة مصادر ومعدلات أسمدة الفوسفات المختلفة ، أوضحت النتائج أن هناك إختلافات معنوية بين

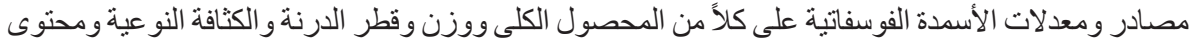

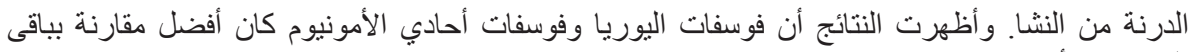

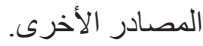

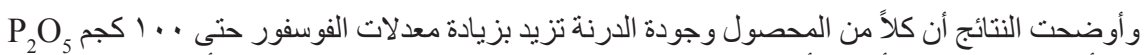

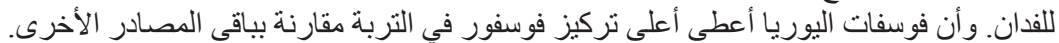

